\title{
PERAN MAHKAMAH INTERNASIONAL DALAM PENYELESAIAN SENGKETA LINGKUNGAN HIDUP INTERNASIONAL
}

\author{
Oleh : \\ Nur Asyraf Munif Junaidy Nasser \\ Program Magister Hubungan Internasional Fakultas Ilmu Sosial dan Ilmu Politik Universitas Indonesia \\ J1. Prof. Dr. Selo Soemardjan, Kota Depok, Jawa Barat 16424 \\ Email : acf0803@gmail.com
}

\begin{abstract}
Abstrak
Lingkungan hidup tidak dapat dipisahkan dari gerakan dunia untuk memberikan perhatian lebih besar kepada lingkungan hidup, mengingat kenyataan bahwa lingkungan hidup telah menjadi masalah yang perlu ditanggulangi bersama demi kelangsungan hidup di bumi ini. Perbuatan yang tidak bertanggungjawab oleh pihak-pihak yang mengambil keuntungan dari alam tersebut dapat memicu suatu reaksi baik dari masyarakat lokal maupun internasional. Sengketa lingkungan hidup merupakan perselisihan antara dua pihak atau lebih yang ditimbulkan oleh adanya atau diduga adanya pencemaran dan/atau perusakan lingkungan hidup. Negara yang mengalami kerugian akibat terkena dampak dari eksploitasi maupun pencemaran lingkungan oleh negara lain dapat meminta ganti rugi serta tanggung jawab. Tulisan ini mengulas mengenai peran yang dijalankan oleh Mahkamah Internasional dalam menyelesaikan sengketa lingkungan hidup internasional. Mahkamah Internasional merupakan organ utama PBB. Dalam upaya penyelesaian perkara ke Mahkamah Internasional bukanlah merupakan kewajiban negara namun hanya bersifat fakultatif. Negara dalam memilih cara-cara penyelesaian sengketa dapat melalui berbagai cara lain seperti diplomasi, mediasi, arbitrasi, dan cara-cara lain yang dilakukan secara damai. Dengan demikian penyelesaian perkara yang diajukan ke Mahkamah Internasional bersifat pilihan dan atas dasar sukarela bagi pihak-pihak yang bersengketa
\end{abstract}

Kata kunci: Lingkungan hidup, Mahkamah Internasional, Sengketa.

\begin{abstract}
The environment can't be separated from the world movement to give greater attention to the environment, given the fact that the environment has become a problem that needs to be tackled together for the sake of survival on this earth. Unresponsible acts by those who take advantage of such nature may trigger a reaction from both local and international communities. Environmental disputes are disputes between two or more parties arising from the presence or suspicion of environmental pollution and I or damage. Countries suffering losses from exploitation and environmental pollution by other countries may seek redress and liability. This paper reviews the roles of the International Court of Justice in resolving international environmental disputes. The International Court of Justice is the main organ of the United Nations. In an effort to settle the case to the International Court of Justice is not a state obligation but only facultative. States in the choice of ways of dispute resolution can be through other means such as diplomacy, mediation, arbitration and other peaceful means. Thus the settlement of cases filed with the International Court of Justice is optional and voluntary to the parties to the dispute.
\end{abstract}

Keyword: The Environment, the International Court of Justice, the disputes. 


\section{PENDAHULUAN}

Lingkungan hidup adalah kesatuan ruang dengan semua benda, daya, keadaan, dan makhluk hidup, termasuk manusia, dan perilakunya, yang memengaruhi kelangsungan perikehidupan dan kesejahteraan manusia serta makhluk hidup lain dan dapat mempengaruhi hidupnya. ${ }^{1}$ Problem lingkungan hidup dewasa ini menghadapi masalah yang cukup kompleks dan dilematis. Atas nama 'pembangunan' dan 'ekonomi', negara dan perusahaan-perusahaan multinasional secara terus menerus memanfaatkan tanah, air, hutan dan kandungan bumi lainnya tanpa henti. Hal tersebut kemudian yang mendorong terjadinya degradasi lingkungan hidup. Keraf kemudian secara kasar membagi lima macam krisis dan bencana lingkungan hidup global. Diantaranya, kerusakan lingkungan hidup, pencemaran lingkungan hidup, kepunahan sumber daya alam dan lingkungan hidup, kekacauan iklim global serta masalah sosial terkait lingkungan hidup. ${ }^{2}$

Keberhasilan pembangunan tidak hanya diukur dari besarnya pertumbuhan ekonomi dantercapainya pemerataan tetapi juga kelestariannya lingkungan di mana pembangunan itu berlangsung. Jika lingkungan rusak maka sumber-sumber (resources) untuk pembangunan itu sendiri akan semakin menipis dan langka. Lingkungan sebagai tempat hidup akan terasa sesak dan tidak nyaman. Dengan demikian maka kerusakan lingkungan akan mengancam tidak saja terhadap keberlanjutan pembangunan itu sendiri tetapi juga akan mengancam eksistensi manusia. Perubahan lingkungan sangat ditentukan oleh perbuatan manusia.

\footnotetext{
${ }^{1}$ N.H.T Siahaan Hukum lingkungan dan ekologi pembangunan, Jakarta, Erlangga , 2004 hlm $4{ }^{2}$ Keraf, A.S. (2010). Etika Lingkungan Hidup. Jakarta: PT Kompas Media Nusantara.
}

Keadaan alam yang ada secara fisik dapat dimanfaatkan untuk kepentingan manusia dalam mengupayakan kehidupan yang lebih baik dan sehat, menjadi tidak baik dan tidak sehat atau dapat pula sebaliknya, apabila pemanfaatanya tidak digunakan sesuai dengan kemampuan serta melihat situasinya.

Perhatian terhadap masalah lingkungan hidup tidak hanya sebatas masalah lokal atau nasional tetapi juga merupakan masalah internasional. Kebutuhan terhadap alam yang semakin meningkat mengakibatkan pencemaran lingkungan menjadi persoalan lintas Negara yang kemudian dikenal sebagai sengketa lingkungan hidup internasional. Pencemaran tersebut dapat berupa emisi udara, pencemaran sungai, kebakaran hutan, pencemaran minyak di lautan. Dalam perkembangannya, lingkungan tidak dapat dipisahkan dari gerakan dunia untuk memberikan perhatian lebih besar kepada lingkungan hidup, mengingat kenyataan bahwa lingkungan hidup telah menjadi masalah yang perlu ditanggulangi bersama demi kelangsungan hidup di bumi ini. Perbuatan yang tidak bertanggungjawab oleh pihak-pihak yang mengambil keuntungan dari alam tersebut dapat memicu suatu reaksi baik dari masyarakat lokal maupun internasional. Sengketa lingkungan hidup merupakan perselisihan antara dua pihak atau lebih yang ditimbulkan oleh adanya atau diduga adanya pencemaran dan/atau perusakan lingkungan hidup. ${ }^{2}$

Mengenai masalah penyelesaian sengketa lingkungan hidup internasional didasarkan pada Prinsip 26 Deklarasi Rio 1992. Pasal 2 ayat (3) Piagam PBB kemudian menentukan bahwa segenap anggota PBB harus menyelesaikan

\footnotetext{
${ }^{2}$ Undang-Undang Republik Indonesia Nomor 32 Tahun 2009 Tentang Perlindungan Dan Pengelolaan Lingkungan Hidup. Bab 1 Butir 25.
} 
sengketa internasional dengan jalan damai dan mempergunakan cara-cara sedemikian rupa sehingga perdamaian dan keamanan internasional, serta keadilan tidak terancam. Prosedur dan mekanisme mengenai penyelesaian sengketa secara umum diatur oleh Pasal 33 Piagam PBB. Untuk menyelesaikan sengketa dengan jalan damai yang sesuai dengan asas-asas keadilan dan hukum internasional, maka diperlukan badan yang berdiri sendiri dan independen. Badan ini tidak boleh dipengaruhi oleh kepentingan pihak tertentu dan harus bebas dari segala pengaruh.

Oleh karena itu, penyelesaian secara hukum dewasa ini dapat ditempuh salah satunya melalui Mahkamah Internasional. Mahkamah Internasional dalam rangka PBB disebut Mahkamah Internasional (International Court of Justice - ICJ). Menurut pasal 92 Piagam PBB disebut statute ICJ didasarkan pada Statuta PCIJ dan merupakan bagian yang tidak terpisahkan dari Piagam PBB. Dikarenakan peran Mahkamah Internasional begitu penting dalam penyelesaian sengketa internasional, maka dalam tulisan ini, penulis tertarik untuk memaparkan lebih jauh mengenai Mahkamah Internasional terutama dalam penyelesaian sengketa lingkungan hidup internasional.

\section{PEMBAHASAN}

Mahkamah Internasional (The International Court of Justice) merupakan badan pengadilan internasional resmi yang bersifat tetap dan bertugas untuk memeriksa dan memutus perkara-perkara yang diajukan kepadanya. Pada bagian ini, penulis akan memaparkan mengenai kedudukan dan dasar hukum Mahkamah Internasional, batasan penyelesaian sengketa, serta prosedur penyelesaian sengketa internasional oleh Mahkamah
Internasional, sehingga akan menggambarkan sejauh mana peran yang dapat dijalankan oleh Mahkamah Internasional.

\subsection{Kedudukan dan Dasar Hukum Mahkamah Internasional}

Mahkamah berkedudukan di Den Haag, Belanda, dan didirikan pada tahun 1945 berdasarkan pada Piagam PBB. Namun, Mahkamah ini mulai bertugas sejak tahun 1946 sebagai pengganti Mahkamah Internasional Permanen (Permanent Court of International Justice). Secara keseluruhan, ada 5 (lima) aturan yang berkenaan dengan Mahkmah Internasional sebagai sebuah Organisasi Internasional. Adapun kelima aturan tersebut adalah :

a) Piagam PBB Tahun 1945

Di dalam Piagam PBB 1945, dasar hukum yang berkenaan tentang Mahkamah Internasional terdapat dalam BAB XIV tentang Mahkamah Internasional sebanyak 5 pasal yaitu Pasal 92 sampai dengan Pasal 96.

b) Statuta Mahkamah Internasional Tahun 1945

Dalam Statuta Mahkamah Internasional sendiri, ketentuan yang berkenaan dengan proses beracara terletak pada BAB III yang mengatur tentang Procedure dan BAB IV yang memuat tentang Advisory Opinion. Ada 26 pasal mulai dari Pasal 39 sampai dengan Pasal 46 yang tercantum di dalam BAB III, sementara di dalam BAB IV hanya terdapat 4 pasal yakni dari Pasal 65 hingga Pasal 68. 
c) Rules of the Court Tahun 1970 yang telah diamandemen pada tanggal 5 Desember 2000

Dasar hukum yang ketiga yaitu Aturan Mahkamah atau lebih dikenal dengan Rules of the Court yang terdiri dari 108 pasal. Aturan ini dibuat pada tahun 1970 dan telah mengalami beberapa amandemen dimana amandemen terakhir adalah pada tanggal 5 Desember 2000. Aturan ini berlaku atau entry into force sejak tanggal 1 Februari 2001 dan bersifat tidak berlaku surut atau non-retroaktif

d) Practice Directions I - IX

Dasar hukum yang berikutnya adalah Panduan Praktek (Practice Directions) I-IX. Ada 9 panduan praktek yang dijadikan dasar untuk melakukan proses beracara di Mahkamah Internasional. Panduan praktek ini secara umum berkisar tentang surat pembelaan (written pleadings) yang harus dibuat dalam beracara di Mahkamah Internasional.

e) Resolution Concerning the Internal Judicial Practice of the Court yang diadopsi pada tanggal 12 April 1976 dari Pasal 19 Rules of the Court

Dasar hukum terakhir dari proses beracara di MI adalah Resolusi tentang Praktek Judisial Internal dari Mahkamah (Resolution Concerning the Internal Judicial Practice of the Court), (1976). Resolusi ini terdiri dari 10 ketentuan tentang beracara di MI yang telah diadopsi pada tanggal 12 Apil 1976. Resolusi ini menggantikan resolusi yang sama tentang Internal Judicial Practice yang dikeluarkan pada tanggal 5 Juli 1968.

PBB memiliki beberapa organ utama diantaranya Majelis Umum, Dewan Keamanan, Dewan perwalian, Sekretariat Jenderal dan Dewan Ekonomi dan Sosial serta Mahkamah Internasional. Hal ini ditegaskan didalam pasal 7 (1) Piagam PBB yang menyatakan :

"There are established as the principal organs of the United Nations a General Assembly, a Security Council, an Economic and Social Council, a Trusteeship Council, an International Court of Justice and a Secretariat".

Karena memiliki kedudukan yang sederajat dengan organ-organ utama PBB yang lainnya maka Mahkamah Internasional bukan merupakan badan peradilan umum PBB yang bersifat memaksa terhadap organ lainnya. Mahkamah hanya memiliki kewenangan untuk memberi nasihat apabila diminta dan pemberian nasihat itu tidak mengikat atau meiliki kedudukan lebih tinggi dari keputusan Majelis Umum PBB.

Demikian juga halnya dalam pemeriksaan berbagai perkara yang diajukan kepada Mahkamah Internasional maka organ-organ PBB lainnya tidak boleh mencampuri urusan Mahkamah.

Hal yang penting dalam sistem PBB adalah meletakkan Mahkamah Internasional sebagai organ utama dalam sistem PBB. $^{3}$ Berdasarkan ketentuan tersebut maka Mahkamah Internasional merupakan bagian yang integral dalam sistem PBB. Sebagai

\footnotetext{
${ }^{3}$ Pasal 7 Piagam PBB
} 
organ PBB, Mahkamah Internasional sangat dekat dengan tujuan PBB. Ini berarti bahwa Mahkamah Internasional sebagai organ utama PBB menunjukkan bahwa penyelesaian sengketa melalui pengadilan sebagai suatu komponen penting dalam mekanisme perdamaian internasional. Sebagai organ utama $\mathrm{PBB}$ maka pelaksanaan tugasnya sejalan dengan tujuan PBB yang ditentukan dalam Piagam. Status Mahkamah Internasional sebagai organ utama PBB menentukan tanggungjawabnya dan kesamaan derajat dengan organ utama lainnya sesuai dengan kewenangannya. ${ }^{4} \quad$ Mahkamah Internasional adalah satu-satunya organ utama disamping Majelis Umum PBB yang tidak menyerahkan laporan tahunan kepada Majelis Umum PBB.

Namun, sejak tahun 1968 telah berubah dimana Mahkamah Internasional mulai memberikan laporannya kepada Majelis Umum PBB. Mahkamah Internasional menjelaskan bahwa inovasi ini didasarkan bahwa laporan yang demikian akan memberikan pengertian akan fungsinya dan aktivitasnya dalam rangka kerja $\mathrm{PBB} .{ }^{6}$ Kedudukan Mahkamah Internasional ini memang unik, dimana sebagai salah satu organ utama $\mathrm{PBB}$, mereka harus benar-benar menunjukkan kemandiriannya sebagai suatu organ atau badan pengadilan. ${ }^{5}$ Semua negara yang menjadi anggota Statuta Mahkamah dapat menyerahkan kepada Mahkamah Internasional

${ }^{4}$ Suwardi, Sri Setianingsih, Penyelesaian Sengketa Internasional, Jakarta, UI-Press, 2006, hlm. $64{ }^{6}$ Ibid, hlm 65

${ }^{5}$ Ibid perkara-perkara apa saja yang mereka inginkan.

\subsection{Batasan Penyelesaian Sengketa oleh Mahkamah Internasional}

Penyelesaian sengketa lingkungan hidup internasional merupakan salah satu permasalahan yang menarik untuk dikaji. Umumnya, sengketa lingkungan hidup internasional menyangkut persoalan pertanggungjawaban (responsibility) dan ganti rugi (compensation). Deklarasi Stockhlom 1972 telah menegaskan dalam Prinsip 22 yang menyatakan perlunya dikembangkan hukum internasional mengenai kewajiban dan kompensasi terhadap korban pencemaran. Prinsip ini ditegaskan kembali dalam Deklarasi Rio 1992 pada Prinsip 13 yaitu perlunya dikembangkan hukum nasional dan internasional mengenai ganti rugi. Menurut beberapa ahli hukum internasional penyelesaian sengketa dapat digolongkan dalam 2 kategori yaitu : ${ }^{6}$

a) Penyelesaian sengketa secara damai.

Para pihak yang terlibat sengketa bermufakat untuk mencari penyelesaian secara bersahabat.

b) Penyelesaian sengketa secara paksa.

Pemecahannya ditempuh secara paksa atau dengan kekerasan.

Kategori mengenai penyelesaian sengketa dibidang lingkungan hidup umumnya dilakukan secara damai. Sedangkan penyelesaian sengketa secara paksa dengan kekerasan dapat

\footnotetext{
${ }^{6}$ Starke, JG. 1989. Introduction to International Law diterjemahkan oleh Sumitro L.S. Danuredjo, Pengantar Hukum Internasional, Aksara Persada Indonesia, Jakarta, hlm 171.
} 
terjadi berkaitan dengan masalah perebutan sumber daya alam atau sengketa lainnya yang mengakibatkan tindakan paksaan oleh suatu negara kepada negara lainnya. Dalam tulisan ini umumnya dibahas penyelesaian sengketa secara damai. Dalam proses penyelesaian sengketa, Mahkamah Internasional bersifat pasif, artinya hanya akan bereaksi dan mengambil tindakan-tindakan bila ada pihakpihak berperkara yang mengajukan ke Mahkamah Internasional. Dengan kata lain Mahkamah Internasional tidak dapat mengambil inisiatif terlebih dahulu untuk memulai suatu perkara. Dalam mengajukan perkara terdapat 2 tugas mahkamah, yaitu :

a) Contentious Jurisdiction

Yuridiksi mahkamah ini merupakan kewenangan untuk mengadili suatu sengketa antara 2 negara atau lebih (Jurisdiction Ratione Personae). Yuridiksi Mahkamah Internasional dapat dilaksanakan dengan tiga cara, yaitu :

1. Berdasarkan Pasal 36 ayat (1) Statuta Mahkamah Internasional, dimana yurisdiksi pengadilan mencakup semua sengketa yang diserahkan oleh para pihak dan semua persoalan yang ditetapkan dalam Piagam PBB yang dituangkan dalam perjanjian - perjanjian atau konvensi - konvensi internasional.

2. Doktrin Forum Propogatum, dimana menurut doktrin ini, yurisdiksi propogated timbul manakala hanya satu negara yang menyatakan dengan tegas persetujuannya atas Yurisdiksi Mahkamah. Kesepakatan pihak lainnya diberikan secra diamdiam, tidak tegas atau tersirat saja.

3. The Optional Clause Pasal 36 Ayat 2 Statuta Mahkamah Internasional. Berdasarkan Pasal 36 ayat (2) yaitu klausul pilihan, dinyatakan bahwa negara-negara peserta pada Statute dapat setiap waktu menyatakan penerimaan wajib ipso facto yurisdiksi Mahkamah Internasional dan tanpa adanya perjanjian khusus terhadap negara yang menerima kewajiban serupa atas semua sengketa hukum.

b) Noncontentious (Advisory) Jurisdiction

Yaitu dasar hukum yurisdiksi mahkamah untuk memberi nasehat atau pertimbangan hukum kepada organ utama atau organ PBB lainnya. Nasihat hukum yang diberikan terbatas sifatnya, hanya terkait dengan ruang lingkup kegiatan atau aktifitas dari 5 badan atau organ utama dan 16 badan khusus PBB.

Sebenarnya hanya negara sebagai pihak yang boleh mengajukan perkara kepada Mahkamah Internasional. Karena itu perseorangan, badan hukum, serta organisasi internasional tidak dapat menjadi pihak untuk berperkara ke Mahkamah internasional. Namun demikian, berdasarkan Advisory opinion tanggal 11 April 1949 Mahkamah Internasional secara tegas 
menyatakan bahwa PBB adalah merupakan pribadi hukum yang dapat mengajukan klaim internasional atau gugatan terhadap negara. Advisory Opinion ini telah membuka kesempatan kepada PBB untuk menjadi pihak dalam perkara kontradiktor (contentious case).

Dalam upaya penyelesaian perkara ke Mahkamah Internasional bukanlah merupakan kewajiban negara namun hanya bersifat fakultatif. Artinya negara dalam memilih cara-cara penyelesaian sengketa dapat melalui berbagai cara lain seperti diplomasi, mediasi, arbitrasi, dan cara-cara lain yang dilakukan secara damai. Dengan demikian penyelesaian perkara yang diajukan ke Mahkamah Internasional bersifat pilihan dan atas dasar sukarela bagi pihak-pihak yang bersengketa. Hal ini sesuai dengan Pasal 33 ayat (1) Piagam PBB. Meskipun Mahkamah Internasional adalah merupakan organ utama PBB dan anggota $\mathrm{PBB}$ otomatis dapat berperkara melalui Mahkamah Internasional, namun dalam kenyataannya bukanlah merupakan kewajiban untuk menyelesaikan sengketa pada badan peradilan ini. Beberapa negara tidak berkemauan untuk menyelesaikan perkaranya melalui Mahkamah Internasional.

Sebagai contoh, dalam perkara Kepulauan Malvinas tahun 1955 dimana Inggris menggugat Argentina dan Chili ke Mahkamah Internasional namun Chili dan Argentina menolak kewenangan Mahkamah Internasional untuk memeriksa perkara ini. Perlu dicatat bahwa para hakim yang duduk di Mahkamah Internasional tidak mewakili negaranya, namun dipilih dan diangkat berdasarkan persyaratan yang bersifat individual seperti keahliannya dalam ilmu hukum, kejujuran serta memiliki moral yang baik. Penunjukan para hakim ini diusulkan dan dicalonkan oleh negara-negara ke Majelis Umum PBB dan Dewan Keamanan PBB.

\subsection{Proses Penyelesaian Sengketa oleh Mahkamah Internasional}

Pengajuan perkara ke Mahkamah Internasional dapat menggunakan 2 cara, yaitu :

a) Bila pihak-pihak yang berperkara telah memiliki perjanjian khusus (special agreement) maka perkara dapat dimasukkan dengan pemberitahuan melalui panitera Mahkamah.

b) Perkara dapat diajukan secara sepihak (dalam hal tidak adanya perjanjian/persetujuan tertulis).

Surat pengajuan permohonan perkara harus ditandatangani oleh wakil negara atau perwakilan diplomatik yang berkedudukan di tempat mahkamak Internasional berada. Setelah panitera menerima, maka salinan pengajuan perkara tersebut disahkan kemudian salinannya dikirim kepada negara tergugat dan hakim - hakim Mahkamah Internasional. Pemberitahuan juga disampaikan kepada anggota PBB melalui Sekretariat Jenderal. Setelah itu, dalam acara pemeriksaan dilakukan melalui sidang acara tertulis dan 
acara lisan. Dalam acara tertulis, dilakukan sesi tanya jawab secara tertulis antara pihak tergugat dan penggugat. Setelah acara tertulis ditutup, lalu dimulai acara lisan atau hearing. Acara ini biasanya dipimpin langsung oleh Presiden atau Wakil Presiden Mahkamah Internasional, dengan menanyakan saksi-saksi maupun saksi ahli atau juga wakilwakil dari para pihak seperti penasihat hukum dan pengacara. Dalam acara ini dapat bersifat terbuka atau tertutup dimana bergantung pada keinginan para pihak.

Setelah semuanya selesai, maka dilakukan pengambilan keputusan yang dilakukan berdasarkan suara mayoritas para hakim. Keputusan Mahkamah bersifat final dan tidak ada banding, kecuali untuk hal-hal yang bersifat penafsiran dari keputusan itu sendiri. Dalam persidangannya untuk jenis perkaraperkara tertentu dapat dimungkinkan dibentuknya suatu kamar sengketa (chamber) yaitu sidang majelis hakim yang lebih kecil. Sebagai contoh, Chamber of Environmental Dispute untuk menangani Case concerning Certain Phosphate Lands in Nauru (sengketa antara Nauru dan Australia) dan Gabcikovo-Nagymaros Project (sengketa antara Hungary melawan Slovakia). Namun, pembentukan kamar sengketa ini hanya berlaku bagi kewenangan untuk memeriksa perkara kontradiktor sehingga tidak berlaku dalam persidangan advisory opinion.

\subsection{Peran Mahkamah Internasional Dalam Hukum Lingkungan}

Dalam menghadapi persoalanpersoalan lingkungan hidup yang dinamis, nampaknya Mahkamah
Internasional dituntut mampu untuk menyesuaikan perkembangan zaman. Hal ini dapat terlihat dengan adanya perkembangan demokratisasi khususnya tuntutan negara-negara baru sejak berakhirnya Perang Dunia II. Selain itu, partisipasi masyarakat sipil global melalui berbagai kegiatan internasional semakin nyata dengan makin berperannya Non Government Organization (NGO), indegenous people, asosiasiasosiasi dan berbagai kelompok kepentingan yang menuntut adanya hak-hak yang sama terutama dengan tujuan untuk menciptakan lingkungan hidup yang berkeadilan. Kesadaran masyarakat sipil terkait pelestarian lingkungan hidup juga semakin berkembang. Hal ini ditambah lagi proses globalisasi yang nyata dimana batas-batas negara semakin menipis. Dengan keberadaan Mahkamah Internasional, maka diharapkan akan mampu menangani berbagai persoalan global khususnya mengenai sengketa lingkungan hidup internasional yang masih minim penegakan hukum dan sanksinya.

Kategori mengenai penyelesaian sengketa dibidang lingkungan hidup umumnya dilakukan secara damai. Dalam proses penyelesaian sengketa, Mahkamah Internasional bersifat pasif, artinya hanya akan bereaksi dan mengambil tindakan-tindakan bila ada pihak-pihak berperkara yang mengajukan ke Mahkamah Internasional. Dengan kata lain Mahkamah Internasional tidak dapat mengambil inisiatif terlebih dahulu untuk memulai suatu perkara. Sehingga peran Mahkamah Internasional dalam sengketa lingkungan hidup internasional juga bergantung pada sukarela dan kesepakatan negara dalam 
menyelesaikan sengketa dimana sesuai dengan Pasal 33 ayat (1) Piagam PBB. Negara dalam memilih cara-cara penyelesaian sengketa dapat melalui berbagai cara lain seperti diplomasi, mediasi, arbitrasi, dan cara-cara lain yang dilakukan secara damai. Beberapa negara juga tidak berkemauan untuk menyelesaikan perkaranya melalui Mahkamah Internasional.

\section{PENUTUP}

Kasus-kasus yang akan dihadapi oleh Mahkamah Internasional tidak hanya persoalanpersoalan politik saja. Beberapa kasus lingkungan hidup khususnya yang dikategorikan sebagai common heritage of mankind diharapkan akan menjadi perhatian Mahkamah Internasional. Eksistensi aktor non-negara seperti masyarakat sipil global dimana salah satunya Non Governmental Organization (NGO), menuntut penegakan lingkungan hidup global yang adil. Mahkamah Internasional menjadi badan resmi yang diharapkan mampu menegakkan hukum lingkungan internasional dimana merupakan hal yang sangat penting karena degradasi lingkungan terjadi secara terus menerus. Mahkamah Internasional harusnya membuka kesempatan kepada aktor non-negara untuk mengajukan diri untuk menjadi pihak yang berperkara karena peran aktor non-negara yang semakin kuat dalam isu lingkungan hidup dan semakin biasnya batas antar negara.

Negara yang mengalami kerugian akibat terkena dampak dari eksploitasi maupun pencemaran lingkungan oleh negara lain dapat meminta ganti rugi serta tanggung jawab. Negara merupakan bagian dari dinamika masyarakat modern yang menjadi penyebab dari krisis lingkungan masa kini. ${ }^{7}$ Memang, negara dianggap sebagai aktor yang berada dalam posisi sulit bahkan tidak mampu untuk mengelola dan menciptakan lingkungan hidup yang berkeadilan, namun negara jugalah yang mampu melindungi wilayahnya dari pencemaran lingkungan oleh negara lain.

Dalam proses penyelesaian sengketa, Mahkamah Internasional bersifat pasif, artinya hanya akan bereaksi dan mengambil tindakan-tindakan bila ada pihak-pihak berperkara yang mengajukan ke Mahkamah Internasional. Dengan kata lain Mahkamah Internasional tidak dapat mengambil inisiatif terlebih dahulu untuk memulai suatu perkara. Sehingga peran Mahkamah Internasional dalam sengketa lingkungan hidup internasional juga bergantung pada sukarela dan kesepakatan negara dalam menyelesaikan sengketa dimana sesuai dengan Pasal 33 ayat (1) Piagam PBB.

\section{DAFTAR PUSTAKA}

\section{Buku dan Jurnal :}

Keraf, A.S. (2010). Etika Lingkungan Hidup. Jakarta: PT Kompas Media Nusantara.

N.H.T Siahaan. (2004). Hukum lingkungan dan ekologi pembangunan. Jakarta. Erlangga.

Paterson, Matthew. (2001). dalam Scott Burchill, et al. Theories of International Relations, Palgrave. (p. 282).

Suwardi, Sri Setianingsih. (2006). Penyelesaian Sengketa Internasional. Jakarta. UIPress.

\footnotetext{
${ }^{7}$ Paterson, Matthew. (2001). dalam Scott Burchill, et al. Theories of International Relations, Palgrave. ( $\mathrm{p}$. 282).
} 
Peran Mahkamah Internasional Dalam Penyelesaian

Sengketa Lingkungan Hidup Internasional

Starke, JG. (1989). Introduction to International Law diterjemahkan oleh Sumitro L.S.

Danuredjo. Pengantar Hukum Internasional. Aksara Persada Indonesia. Jakarta.

\section{Dokumen :}

Undang-Undang Republik Indonesia Nomor 32 Tahun 2009 Tentang Perlindungan Dan Pengelolaan Lingkungan Hidup.

Piagam Perserikatan Bangsa-Bangsa Tahun 1945.

Statuta Mahkamah Internasional Tahun 1945. 